\title{
Insurance of No-fault Responsibility in Medicine
}

\author{
Miroslav DŽIDIĆ \& NiKOlinA MALETA
}

\begin{abstract}
Professional liability insurance in medicine based on the nofault principle is not a novel legal concept, but it has gained popularity in recent years. The reason for this is because the classic professional liability system that exists in most European countries is obsolete. The basic shortcomings of the traditional insurance model are the overwhelming amount of litigation before the courts and the associated costs that are associated with it. At a time when modern medicine emphasizes the importance of patient education and awareness, which includes also informing patients of both their legal rights and obligations in connection with the medical treatment process, it is very difficult to retain the traditional insurance model where the physician's liability is premised solely on the physician's fault. Medicine is a humane profession and as such requires the greatest possible protection for health care users as well as for those who perform this extremely important activity for the society. This paper emphasizes the advantages of the no-fault liability insurance model and compares it with other insurance models in the field of medicine. The authors make suggestions for possible reforms to the classic medical professional liability insurance model in Bosnia and Herzegovina.
\end{abstract}

Keywords: • No-fault Insurance • Professional Responsibility • Compensation of the Damage $\bullet$ Injury $\bullet$ Physician $\bullet$ Patient $\bullet$

\footnotetext{
CoRReSPONDENCE ADDRESS: Miroslav Džidić, PhD, Professor, Faculty of Law University of Mostar, Matice Hrvatske bb, 88000 Mostar, Bosnia and Herzegovina, e-mail: miroslavdzidic@gmail.com. Nikolina Maleta, PhD, Faculty of Law University of Mostar, Matice hrvatske bb, 88000 Mostar, Bosnia and Herzegovina, email: nikolina.maleta@pf.sum.ba.
} 

Medical personnel have a professional obligation to treat their patients conscientiously and in accordance with the applicable medical standards of care. Given the preeminent role of medicine in society and the sensitivities of healthcare users, laws regulating the healthcare profession for injuries and harm they cause their patients as a result of their work and related necessary patient protection is of exceptional importance. In their practice, physicians and other health care employees should respect the rules of the medical profession, including rules of professional responsibility, and should make every effort to carry out their work professionally and conscientiously. In most instances they do so and they achieve fine and in many cases even remarkable results. However, despite their best efforts, and even when healthcare providers adhere fully to all of the professional rules of conduct, mistakes sometime occur which lead to patient injury and damage.

Most legal systems regulate the professional responsibility of healthcare professionals for damage caused by their mistakes or omissions. These systems are usually fault-based and from a legal standpoint are premised upon a breach of contract between the medical professional and the patient. Accordingly, if the patient suffers injury and proves the injury was due to the fault of the healthcare professional, then the patient is said to have proven that the healthcare professional breached the contract and is responsible for the patient's damages sustained. All of that is sensible enough. However, a reasonable question appears: Should a patient be denied compensation in the case where he or she suffered injury/damage as a direct result of receiving medical treatment, but where the injury/damage was not caused by the "fault" (i.e. a negligent act or omission) of the treating healthcare professional? For example, such damage may result from the unforeseen failure of the medical equipment used for diagnosis or treatment. In most countries, patients have no legal recourse for such injuries since they are being regulated as an exception to the liability of the healthcare provider due to the categorization of such liability as dangerous product liability. A different result obtains in countries with no-fault systems of insurance responsibility for healthcare professionals. Those countries have implemented rules and laws providing insurance coverage to protect injured patients regardless of the healthcare provider's fault.

Malpractice insurance provides coverage for damages caused by those practicing in various professions and occupations, when the damage they caused was the direct result of their breach of professional obligations to their clients, i.e., their conduct fell below the applicable standard of care, resulting in breach of duty and proximately caused injury/damage. (Ćurković, 2017: 184). In medicine, this insurance can provide coverage on the basis of breach of professional responsibility or liability, or on responsibility for damages caused by fault, as well as for the damage that is not the fault of a healthcare professional. Both responsibility and 
liability ${ }^{1}$, have their own advantages and disadvantages. The appropriateness of one or another system varies from the point of view of the patients and the healthcare providers and medical institutions, and in a completely different way, how these disparate insurance systems of responsibility are seen by the insurers themselves. Furthermore, the elements of both systems of responsibility for medical damage with regard to the legal interests of patients, as well as the insurer's responsibility to cover the risks assumed, particularly in the no-fault professional liability insurance system, are discussed in this paper.

\section{Professional liability insurance}

Liability insurance can be considered to be a subcomponent of general insurance, that is, insurance that has the purpose of providing compensation for damage due to another's liability (Džidić \& Ćurković, 2017: 227). Liability insurance serves the function of protecting the injured person in such a way as to facilitate and accelerate the payment of compensation for the suffered damage (which without applicable insurance might well remain uncompensated due to, for example, the insolvency of the insured) (Belanić, 1991: 553). Besides offering protection to the damaged party in the way of providing monetary compensation, liability insurance also protects the person responsible for causing the damage from possible future debt (which is usually not negligible). Liability insurance can be both compulsory and voluntary. Compulsory liability insurance is that which is mandated and fixed by the legislator. Thus, the most common compulsory liability insurance is vehicular insurance. The reasons that are taken into account when determining whether liability insurance should be compulsory are both the broad spectrum of persons potentially endangered by a particular activity (or things), as well as the amount of potential damages that might be caused as a result of that conduct (Belanić, 1991: 554). For these reasons, it is clear that liability insurance in medicine, i.e. in healthcare services should be compulsory. Medical injuries are frequently severe, perhaps even irreparable, and the number of people both providing and receiving healthcare is huge. For the same reasons it makes sound policy to make insurance compulsory for those operating motorized vehicles (i.e. nearly all people drive) it also makes sense to make insurance compulsory for those providing healthcare services, since everyone requires medical treatment throughout their lives.

Professional liability insurance provides insurance protection for those persons carrying out certain professional activities, such as for example, doctors, lawyers and engineers. The purposes of professional liability insurance are both to protect third parties who suffer damages as a result of the conduct of the persons engaged in professional activities, by providing those injured persons with monetary compensation, and also to protect the providers of the professional services (i.e. the insureds) by indemnifying them for the damages they would otherwise be exposed to and have to pay the injured person themselves. The risk linked to certain

\footnotetext{
${ }^{1}$ Not limited to strict liability for damage caused by dangerous products or activities.
} 
professions such as attorneys, insurance intermediation, security services, healthcare and similar must have insurance Professional liability insurance implies the conclusion of the insurance contract. The conclusion of the insurance contract may be compulsory or voluntary depending on the legal regulations. Professional liability insurance is ordinarily based on the fault principle.

In insurance practice, liability insurance is divided into two types: non-contractual and contractual insurance (Džidić \& Ćurković, 2017: 237). Non-contractual insurance is regulated by the legal framework, i.e. it is legal liability (Džidić \& Ćurković, 2017: 237). Non-contractual insurance can be private and public. Private non-contractual insurance, which is aimed at covering damage inflicted upon third parties by a tort of the insured, thus ensuring its non-contractual liability for damages resulting from the insured's activities in everyday life. Those activities are not related to the performance of a professional activity (Džidić \& Ćurković, 2017: 237 and 295). Private non-contractual insurance is in fact insurance of professional liability. Thus, this type of insurance provides coverage for possible damage to third parties that may be caused by the pursuit of a particular profession.

In addition to the non-contractual professional liability insurance, there is of course contractual professional liability insurance (Belanić, 1991: 555). Unlike noncontractual insurance, which lacks predictability, contractual liability provides a high degree of certainty since, by signing the insurance contract, the identity of the contracting parties is determined in advance.

Professional liability insurance focuses on insurance liability for damages caused by the performance of a particular profession or a certain occupation, and the responsibility for certain professional delinquencies when performing a specific profession (Džidić \& Ćurković, 2017: 239). Thus, professional liability insurance is both non-contractual and contractual. The number and classes of contractual professional liability insurance is growing every day. This is due to the increased number of professions that with their market presence require the regulation of liability insurance.

The physician's professional responsibility also has a civil and criminal character. In criminal law, this responsibility can be based both on strict liability and liability based on fault, while the civil nature of professional responsibility in medicine is only based on liability for fault. The physician must practice medicine in accordance with the rules of the medical profession and pay due attention in order not to cause any damage. The physician's responsibility is usually on the result of some expert errors committed (Radišić, 2017: 26). The error is usually determined according to 
the medical standard ${ }^{2}$ adopted by the healthcare staff. The objective criteria for evaluating the physician's due diligence have recently been expanded. Thus, the physician practicing in a manner contrary to the medical standard is generally responsible even if the mistake otherwise would be forgivable according to the standards of fault-based responsibility (Radišić, 2017: 28). ${ }^{3}$

\subsection{Models of Professional Liability Insurance}

One can distinguish three models in professional liability insurance. The most commonly known model is the so-called classic system regulated in most European countries, and which is used in the majority of EU member states, including Croatia and Slovenia. Bosnia and Herzegovina also have the classic professional responsibility system. The classic system is based on the general national rules of the civil responsibility, most often with liability for fault based on the fault of a healthcare staff, especially a physician (Proso, 2009: 360; see more: Ivanjko \& Džidić, 2017: 96.). Since this system is based on a physician's or healthcare staff's fault, it implies the need for litigation to resolve the dispute, which often is timeconsuming and expensive. Considering the difficulties sometimes associated with proving the insured event; the existence of controversies that are necessarily inevitable when determining the physician's or the healthcare staff's fault for the injury suffered by the patient; and, considering further the fact that litigations for determining the liability for a medical error quickly occupy the media attention, alternatives to the traditional model of solving the responsibilities of physicians and healthcare staff are receiving increased attention (Rakočević, 2011: 21).

The second model of professional liability is the so-called no-fault system of professional responsibility insurance. The basic feature of this system is the imposition of responsibility regardless of the existence of fault on the part of the person responsible for the damage. Therefore, this system protects both the injured patient and the physician or other healthcare provider, because this type of insurance provides broader coverage than does the classic system. Because it is not necessary to prove fault under this system lengthy and expensive litigations can be avoided. Under this system, in place of litigations, there is an administrative procedure that does not determine the physician's fault or his negligence, but instead focuses merely upon the medical error that has endangered the patient's health and whether it has caused any other consequences (Čolović, Petrović \& Tešić, 2015: 86).

The third system of professional liability insurance is a hybrid one that is a combination of the two models previously mentioned. This "mixed system" is primarily represented in France. The French system of professional liability

\footnotetext{
${ }^{2}$ The medical standard is a treatment that can be expected from an average qualified and conscientious physician. More on the content and importance of the term "medical standard" (Radišić, 2017: 26. - 31).

3 The Award dated on 13. 2. 2001 - published in Neue Juristische Wochenschrift, No. 24/2001, p. 1787.
} 
insurance in medicine is largely fault-based, but only for certain categories of accidents. Under certain conditions, the French system provides for liability regardless of fault, hence the so-called no-fault system which is based on the model used in the Scandinavian countries (Proso, 2009: 306).

\section{No-Fault System of the Professional Liability Insurance}

The liability insurance contract based on the principle of no-fault liability is in fact a third-party beneficiary contract. The contracting parties are the insurance company and the health institution and the third-party beneficiary is the patient. The uniqueness of this form of insurance contract lies in the fact that the insurer does not individualize (i.e. name or identify) the third party or the insurance beneficiary, but instead all future patients who suffer damage to their health due to the physician's or the policyholder's actions (regardless of fault) stand as beneficiaries (Rakočević, 2011: 22 and 23). This is a special form of collective professional responsibility insurance (Bush, Chen \& Bush, 1975: 262; Ivanjko \& Džidić, 2017: 102).

It is undeniable that the no-fault system has certain advantages over the other two professional liability insurance models, particularly in comparison with the classic system. As noted above, these advantages are primarily the avoidance of longlasting litigations and guilty plea, as well as the reduction of costs associated with producing the evidence and fixing of damages. The primary aim and purpose of professional responsibility insurance regardless of the fault of the person responsible for the damage is to protect the injured person. This type of insurance liability system is extremely important in medicine. The no-fault insurance model not only provides greater protection for patients but also protects the professional integrity of physicians and other health care professionals. Physicians and other healthcare staff in the no-fault insurance system do not risk the burdens of possible large financial responsibilities (and even bankruptcy) due to patients that suffer damages that would entitle them to significant compensation. The security and comfort of having no-fault insurance protection, in turn, gives physicians and other healthcare professionals greater freedom to practice in a high-risk profession. In addition, this system has another very important advantage. Namely, exonerating healthcare staff from the heavy burden associated with legal liability also encourages and frees them to voluntarily report damages and medical errors. Physicians are less reluctant to report possible errors because they know they are relieved from the possibility of making financial compensation. Another possible advantage of the no-fault system is that it encourages preventative medicine and safer medical practices in the sense that mistakes, instead of being hidden or covered up, can be readily acknowledged and placed in the open with the hope of minimizing the repetition of the same mistakes (Ivanjko \& Džidić, 2017: 102) and eventually detecting systemic errors in their treatment and eliminating them. Ultimately, all of these advantages should result in improved patient care and protection. The no-fault system therefore encourages cooperation between patients and the medical 
personnel who treated them through a joint appearance when determining the damage (Rakočević, 2011: 23).

The no-fault professional liability insurance system is characteristic of the model used in Scandinavian countries. It was first introduced in Sweden in 1975. Prior to that time, Sweden still recognized the classic system of professional liability insurance (Proso, 2009: 363). ${ }^{4}$ Over the years, the no-fault system has expanded from Sweden to other Scandinavian countries, primarily Finland and Norway, and then Denmark, and now to other countries as well. For example, this professional liability insurance model is specifically regulated in New Zealand. According to the New Zealand no-fault system, responsibility is separate from claims for damages, and does not imply fault and rarely results in repressive measures. Therefore, a patient's complaint about the physician's actions is not a prerequisite for submitting claims for damages. However, the patient may concurrently claim compensation for damages and make a complaint about the physician's actions (although the New Zealand tradition and culture do not support claims on physician's actions) (Wallis, 2017: 38-39). If an insured event occurs, the patient will be paid compensation for damages from a special guarantee fund. Claims for damages before the court or through a medical institution are not permitted (Čolović, Petrović \& Tešić, 2015: 82).

In order for a patient to be entitled to compensation for damages in a no-fault insurance scheme there must be a causal link between treatment and injury. Professional liability insurance is compulsory for healthcare institutions. Thus, healthcare institutions must arrange for a liability insurance policy to be in effect to cover the damages stemming from injury to patients caused by their employees practicing their healthcare activities. Both the material and non-material damages resulting from the patient's injury are compensated (Proso, 2009: 363).

The no-fault liability insurance system also provides coverage to physicians and healthcare professionals for any damage they may cause in practicing their profession in order to protect them from personally being responsible for paying large compensation amounts. However, this does not mean that physicians are fully absolved from making financial contributions for their potential liability. To the contrary, they are still obligated to make specific contributions to the fund which forms the "pool" from which compensation is paid. Thus, healthcare institutions (hospitals), not the physicians as individuals, are obliged to conclude insurance contracts, but the physicians themselves are required to make annual financial contributions to a joint compensation fund.

\footnotetext{
${ }^{4}$ See more: Document of the World Bank: Medical Malpractice Systems around the Globe: Examples from the US - tort liability system and the Sweden - no fault system, HNP, 2010: 6.
} 
In all of the aforementioned countries having the no-fault system of professional liability insurance, no-fault insurance is regulated with more or less specifics, differences and adjustments within a single national framework. These specifics and differences relate primarily to the premium insurance payer; to the role of the joint fund; and, to the involvement of the private healthcare provider in covering this type of insurance. This insurance can be based on a common fund or through insurance companies, and the emphasis of insurance can be on the physician's insurance or the patients' insurance (Proso, 2007: 707). Regardless of any national modifications of the general no-fault system, its primary purpose is the same universally: to protect patients and their families, i.e. to provide them compensation for damage when the injury or death occurs irrespective of the physician's fault. Furthermore, the purpose of this system in all countries where it is represented is to relieve physicians from the fear of reporting errors in the treatment process and to eliminate the substantial burden associated with litigation.

The basic feature of no-fault professional liability insurance is the elimination of the requirement on the part of the injured patient to establish that the physician or healthcare provider was at fault in causing the damages complained of. In Sweden, the no-fault system has taken medical injury cases out of the civil court system and placed them into an administrative procedure system, where traditional legal terms like "fault", "negligence" and "responsibility" of a medical practitioner have been excluded. The focus in the administrative procedure instead is on setting the damages' compensation to be paid to the patient as a result of injury that could have been avoided and caused by inappropriate health care (Proso, 2009: 368). Therefore, while the causes of the medical error are examined in order to ensure there is a causal link between the harmful act and the damage, thus entitling the patient to compensation, and further to (hopefully) prevent the same error from recurring, the focus in not on determining the physician's "fault" in the traditional sense, as that is not a relevant consideration under the scheme.

The opponents of the no-fault liability insurance system base most of their critical attitudes on this models' financing (Rakočević, 2011: 26). However, if the costs of litigations represented in the classic model and the financing of the no-fault model are compared, it is clear that the cost of continuing on with the classic model is significantly greater. The no-fault system is largely financed from public revenues, i.e. at the taxpayers' expense, while a smaller portion is funded through premiums paid by the insurance contractor (most often the health institution). ${ }^{5}$ In addition, a significant part of the funding burden is on the shoulders of the physicians themselves who must allocate a certain amount of money to the solidarity fund.

\footnotetext{
${ }^{5}$ See more: Document of the World Bank: Medical Malpractice Systems around the Globe: Examples from the US - tort liability system and the Sweden - no fault system (HNP, 2010: 12).
} 


\section{The Necessity of the Classic System Professional Liability Insurance Reform}

Presently, patients are more keenly aware of their legal rights and obligations as medical consumers than ever before. Personal or family member illnesses are extremely burdensome and stressful on everyone concerned, and cause changes in everyday habits and needs. Treatment itself is generally uncomfortable and often leads to certain adverse psychological consequences and trauma both on the patient as well as on family members. Therefore, if during the course of treatment certain errors occur which, in addition to the disease, cause the patient any additional damage, either material or non-material damage, it is quite certain that such situation requires the urgent and peaceful resolution and mitigation of those negative consequences. Patient education and awareness enables them to better understand their rights, and can assist them in determining when and if their injury was caused by a medical mistake, regardless of the subjective nature of that assessment. The consequence of patients' better understanding their rights is an increased number of litigations, i.e. claims for damages. Thus, in modern times, the classic system of professional liability insurance in medicine has proven inadequate and inefficient due to the high number of medical error claims and litigations which have overwhelmed the court system, the healthcare system, and led to massive transactional costs, to the detriment of not only the medical profession but society more broadly. All of these inefficiencies help explain the increased popularity and efficacy of the no-fault model. The transition away from the classic system of responsibility to the no-fault system has largely transferred the burden of error and damage in medicine from the medical sector to the judicial system. This includes a need to reform the classic professional responsibility system. The advancement of medical knowledge means that the traditional civil liability model based on the fault principle does not always lead to full compensation of the patients' claims (Serwach, 2015: 33). In some of the most economically developed countries, for example, the economic burden imposed under the traditional fault-based insurance model is so enormous that it already negatively affects the overall quality of healthcare (Proso, 2009: 368). In the near future, it therefore would be imperative to introduce a modern compensation damages system to address the problem of medical errors and complications. It is critical that any reformed system provides not only for greater patient protection but also the welfare of physicians in their professional activity. It is suggested that such a system should be in line with those that have been in use in the countries that already have experience with no-fault insurance systems (Ivanjko \& Džidić, 2017: 104).

Another question that arises is the proper role of an insurer in the classic model of professional liability insurance. There appears the necessity to respond whether insurance companies really can cover all the risks that are covered by insurance contract in this class of liability. Under the classic insurance model, in particular in 
the system of voluntary insurance of the professional physicians' liability ${ }^{6}$, each insurance company, when drafting their policy, creates its own conditions, which therefore will vary from company to company, leading to non-standardized professional liability insurance packages and hence the possibility of uncertainty. Under such conditions, insurance companies are not specialized in insuring the professional liability of physicians and are not able to assume full responsibility for and cover every risk that may arise or may occur in this profession. These shortcomings in the traditional fault-based insurance models in the practice of medicine help explain why most countries urgently are trying to find ways to reform the classic models and to introduce fairer, more economical and more easily understood schemes, such as the no-fault model first popularized in the Scandinavian countries. The insurer's position in contracting insurance for professional liability is quite inadequate. Under the insurance contract, the insurer is liable for the damage that may arise from the legal relationship of its insured (health institution/physician) and some third party (patient). For this reason, an appropriate, professional and expert estimation of assumed risks is extremely important, with the emphasis on the Value-at-Risk $\left(\mathrm{VaR}^{7}\right)$. The good risk assessment is also important due to the character of insurance uncertainty (aleatory) (Džidić \& Ćurković, 2017: 237-240).

\section{Physicians' Professional Liability Insurance in Bosnia and Herzegovina}

Bosnia and Herzegovina has a specific constituent structure ${ }^{8}$, and a specific legislative framework. ${ }^{9}$ Additionally, Bosnia and Herzegovina seeks to become a candidate for EU membership while being at the same time a country which borders with the European Union. This is why Bosnia and Herzegovina, in its legislative reform, ordinary follows the example of the Republic of Croatia as its first EU neighbour and the most recently admitted EU member state. Although it is rather

\footnotetext{
${ }^{6}$ In Bosnia and Herzegovina, for example, professional physicians' liability insurance is not compulsory.

${ }^{7}$ Value-at-Risk is used to estimate the overall risk value of the portfolio or the distribution of capital through the marginal contribution to the risk portfolio resulting in a diversified portfolio based on risk value, i.e. VaR. VaR is the popular method which is used by risk management, usually to measure the risk of loss in a specific asset portfolio, provided the likelihood of loss of a certain percentage of the portfolio at market value over a defined period of time (see more: Brandtner \& Kürsten, 2014: 156; Dash Wu \& Olson, 2015: 18; Alizadeh \& Nomikos, 2009: 305).

${ }^{8}$ Bosnia and Herzegovina is divided into two entities, one of which is the Federation of Bosnia and Herzegovina and the other Republika Srpska. Together with entities, the special administrative unit is the Brčko District of Bosnia and Herzegovina.

${ }^{9}$ Most of the legal areas are regulated by special laws at entity's levels and at the level of Brčko Distrikt BiH. The profession of health care is also regulated at the entity's levels instead at the state level.
} 
lagging behind from the legislative solutions of the Republic of Croatia, Bosnia and Herzegovina closely monitors the legal changes that the Republic of Croatia introduces in its legal regulation, including those within the framework of health care and related to the insurance of professional responsibilities of healthcare professionals. So, it is very important for Bosnia and Herzegovina to assess how the Republic of Croatia will fund and otherwise cope with problems associated with the classic professional liability insurance system and what sort of solutions that country might find to compensate for those shortcomings. ${ }^{10}$ The introduction of the no-fault compensation system for the actions of healthcare professionals in conjunction with the introduction of a joint fund to cover payment for the medical injuries' damages incurred by the Republic of Croatian and Bosnia and Herzegovinian patients (if Bosnia and Herzegovina considers introducing changes to its legal system), would certainly shorten the time it would take for patients to ereceive compensation for medical injury and would make the process easier and less expensive (Proso, 2007: 706).

For practicing a particular profession in Bosnia and Herzegovina contractual and non-contractual liability is regulated. This is the case for the healthcare profession as well. The Law on Obligations ${ }^{11}$ regulates liability for fault for damage, unless the damage is caused either by the use of dangerous products or by carrying out a dangerous activity when the responsibility exists regardless of any fault (Article 154). A hospital is responsible for the harmful consequences of otherwise acceptable and generally accepted treatment in medicine, on the principle of fault. In order to compensate a patient for damages sustained, there must be a causal link between the injury done and the damage. ${ }^{12}$ Both material and non-material damages are compensated. Under non-material damage LOO implies physical and mental pain $^{13}$ and fear (Article 200).

\footnotetext{
${ }^{10}$ The Croatian Medical Chamber analyzes the possibility of introducing the no fault system of physician's liability insurance since 2005. but no major steps have been made so far.

11 Official Gazettes of the SFRY No. 29/78, 39/85, 45/89 i 57/89; Official Gazettes of BiH No. 2/92, 13/93 and 13/94; Official Gazettes of Republika Srpska No. 17/93, 3/96, 39/03 and 74/04 (hereinafter: LOO). The Law on Obligations originates from the former Yugoslavian legal system and is introduced in the legal system of Bosnia and Herzegovina with some amendments.

12 From judicial practice; Judgment of the Supreme Court of BiH, Rev. 697/88, dated 4 August 1989 - Bulletin Vs BiH 4/89 - 119. This award has established that the hospital is not responsible for the damage unless a causal link between an unsuccessful surgical procedure and the harmful consequences is established.

${ }^{13}$ Only the psychological (mental) pain resulting from the reduction of life activities, injury, violation of reputation, honor, freedom or personality, then the death of a close person or severe disability of a close person (Article 201, paragraph 3 LOO) to obtain a fair compensation for mental pain.
} 
In the Federation of Bosnia and Herzegovina professional medical liability insurance is not compulsory. ${ }^{14}$ The HealthCare Act $^{15}$ regulates the facultative possibility of insuring professional responsibility of healthcare providers and physicians as individuals. ${ }^{16}$ Physicians in other words may, but they are not obliged to, conclude an insurance contract. The same Act stipulates that patients, among other rights, enjoy the right to compensation for damages sustained (Article 27, paragraph 2), although a shortcoming is that the Act fails to explain the details of this right. ${ }^{17}$ The Act on Medical Activity of the Federation of Bosnia and Herzegovina ${ }^{18}$ regulates compulsory professional liability insurance of a foreign physician who could cause damage while performing a medical activity in $\mathrm{FBiH} .{ }^{19}$ The Act on Patients' Rights, Obligations and Responsibilities of the Federation $\mathrm{BiH}^{20}$ grants patients the right to compensation for the damages suffered due to the professional fault of the physician or a health professional (Article 44). ${ }^{21}$ It is clear from the above that in the Federation of Bosnia and Herzegovina there is no obligation for health institutions and health professionals to conclude an insurance contract for professional liability. A patient who suffers damages caused by a medical error is entitled to compensation for those damages, but that right must be

${ }^{14}$ In Croatia it is compulsory (Article 124. paragraph 4. of the Healthcare Law, Official Gazettes No. 150/08, 71/10, 139/10, 22/11, 84/11, 154/11, 12/12, 35/12, 70/12, 144/12, $82 / 13,159 / 13,22 / 14,154 / 14,70 / 16,131 / 17)$.

In Slovenia it is also regulated as compulsory unsurance (Article 61. Zakona o zdravniški službi, Uradni list RS, št. 72/06, 15/08, 58/07,107/10, 40/12, 88/16).

15 Official Gazettes of the Federation BiH No. 41/10.

${ }^{16}$ Article 137. pharagraphs 3. i 4. Healthcare Act of the FBiH: The healthcare staff can be insured of the responsibility for the damage they might cause by performing health care. An institution where healthcare staff is employed can be insured of liability for damage that healthcare staff employed in this institution may cause in carrying out their healthcare activities.

${ }^{17}$ At the same time, Article 27 paragraph 3 defines as it follows: The rights referred to in paragraph 2 of this Article shall be exercised on the basis of contemporary medical doctrine, professional standards and norms, and in accordance with the possibilities of the healthcare system in the Federation and subject to prior fulfillment of the patients' obligations and responsibilities defined by this law as well as by the regulations on the rights, obligations and responsibilities of the patient.

${ }^{18}$ Official Gazettes of the FBiH No. 56/13.

${ }^{19}$ According to the Article 12. of the Act on Medical Practice FBiH a healthcare institution that engages a foreign physician as a consultant is obliged to obtain the consent of the Federal Ministry of Health and with the request for the consent is obliged, inter alia, to enclose proof of professional liability insurance for damages that could be committed by foreign physician during the medical profession in the Federation (Article 133 paragraph 2).

${ }^{20}$ Official Gazettes of the Federation BiH No. 40/10.

${ }^{21}$ It is about the damage that the in the healthcare treatment patient is suffering on his or her body or the damage that worses his/her health condition. The right to compensation for damage have patient's descendants in the case of patient's death proven caused by a professional error of the physician. 
demonstrated before the court. In order to receive compensation for the damages, it is necessary for the patient to prove the fault of the physician as well as the causal link between the medical error and the caused damage.

In the Republika Srpska professional medical liability is also not compulsory. The Healthcare Act of the Republika Srpska ${ }^{22}$ grants patients the right to compensation for the damage caused to them as a result of professional fault of the healthcare staff. ${ }^{23}$ The same provision is stipulated in the Healthcare Act of Brčko District of Bosnia and Herzegovina. ${ }^{24}$ Republika Srpska, apart from the above-mentioned provisions of the Law on Obligations and the Healthcare Act, does not go further in regulating the liability for damages that the physician may cause in his/her profession. Nonetheless, the situation is the same as in the Federation of $\mathrm{BiH}$. Therefore, medical liability insurance is not regulated by law as compulsory, but rather healthcare providers and physicians may purchase professional liability insurance. In Republika Srpska, the physician's professional liability is regulated as voluntary insurance and is effectuated through professional associations. For example, the Chamber of Physicians of Republika Srpska concluded the insurance contract on the professional liability of its member physicians. This insurance provides coverage for third-party liability due to unexpected and sudden events resulting from a physicians' activity that either has led to an injury, an aggravation of health or the death of a person. ${ }^{25}$

\section{Conclusion}

There are three different models of professional liability insurance in medicine. The most widespread is the classic system that requires proof of fault on the part of the physician or other healthcare professional. In some countries which adhere to this system, including Bosnia and Herzegovina, the professional liability insurance of physicians and medical institutions is not compulsory but voluntary. The second system of physicians' liability is the no-fault system under which the patient receives compensation regardless of whether there is any fault on the part of the physician or other healthcare professional for the injury. Some countries combine

22 Official Gazettes of the RS No. 106/09 i 44/15.

${ }^{23}$ Article 32. of the Healthcare Act of the RS states: A patient who, due to a professional fault of a healthcare staff or a healthcare professional, experiences health damage in his/her healthcare or causes an aggravation in his health condition by professional error, is entitled to compensation for damage in accordance with the law. (2) At the request of the director of a health institution, the competent health clinic shall appoint a five-member Commission to determine the expert error referred to in paragraph 1 of this Article. (3) The competent health chamber shall submit the findings and the opinion of the Commission referred to in paragraph 2 of this Article to the Ministry and to the applicant in order to exercise the rights referred to in paragraph 1 of this Article. (4) The right to compensation for damage can not be excluded or limited in advance.

${ }^{24}$ Official Gazettes of the Brčko District BiH No. 38/11. Article 40 of this Act is the same as Article 32 of the Health Care Act of Republika Srpska.

${ }^{25}$ ee more: http://ssdmrs.org/NewsImages/98_1.pdf (20.2.2018). 
these two systems of professional responsibility insurance, and generally provide coverage for the physicians' liability where there is evidence of fault, except in certain situations that regulate compensation for damage regardless of the physician's fault.

Most legal systems that still adhere to the classic model of liability for damage in medicine are working on reforms consisting either of the introduction of the nofault system of liability insurance or some other alternative model. The no-fault physician's professional liability model has certain advantages, but also some drawbacks which make it less than an ideal model for all legal systems. For example, a no-fault system requires additional funding on the part of taxpayers; +mutual fund financing; and, the solidarity of all those who participate in the guarantee fund. Furthermore, this system has the additional drawback that it does not prevent litigations completely, in particular when the injured patient is not satisfied with the amount of compensation paid out of the fund. One can conclude that the precondition for the implementation of the no-fault physician's professional responsibility insurance is an economically developed and stable country, rich enough to support the functioning of the joint fund for compensation. Bosnia and Herzegovina currently is far from that stage of economic development. However, if we fully follow the Swedish model of no-fault professional liability insurance, we could, as a substitute for the classic insurance model, foresee the introduction of voluntary no-fault insurance. This liability insurance system could be initially introduced on a voluntary basis only in medicine. Over time, due to the substantial benefits it yields over the classic model, it presumably would be implemented as a compulsory insurance model. As an additional ("buffer") phase until the introduction of a compulsory no-fault +medical liability insurance model, there might be a "mixed insurance model" that could be provided that would assume compulsory no-fault liability insurance only in the most severe instances of medical errors and injuries. Thus, the following hierarchy would apply: First, the implemented voluntarily no-fault professional responsibility insurance could be applied; this would be followed by the mixed model; and ultimately, if the mixed system proves not to be a suitable solution, the no-fault system of professional liability insurance could be legally implemented. However, in order to be able to speak about the introduction of no-fault liability insurance in the medical system of Bosnia and Herzegovina, our legislator must firstly regulate compulsory professional liability insurance. Such an obligation already exists in some less sensitive professions such as notaries and security agencies, but injuries in medicine are far more common and the injured persons generally belong to a more socially vulnerable category of the population than typically is the case for those who suffer damages from the acts of attorneys or notaries they employed. Therefore, as a prerequisite for further reform of professional physicians' liability insurance in Bosnia and Herzegovina, it is necessary first to regulate that at least health institutions are obliged to effect the insurance for the professional liability of their healthcare staff. Further, the same obligation should also apply to physicians performing in private practice. Therefore, it is necessary to replace the physician's 
facultative liability insurance with a compulsory one. As long as this issue is not regulated as a preliminary matter, it will not be possible to regulate the optimal model of professional liability insurance in Bosnia and Herzegovina.

The Bosnia and Herzegovinian legislator has failed to recognize the need to reform the medical liability insurance system because the patients' awareness is not yet at the level that would cause the initiation of a high volume of litigation to determine the compensation for the damages due to the patient's injury. When it comes to this stage, and in the near future probably it will, the need for a different regulation of professional liability insurance in medicine will be imposed by itself as a necessity. However, an additional problem is the general awareness on the part of healthcare users about trust in the health system. We think it will take a long time for physicians to have complete freedom to report all the errors that occur in their work without fear of harming their professional reputation. Therefore, with legal changes and the introduction of more contemporary models of professional responsibility, it is necessary to carry out systematic education and training of the entire population on the advantages of transparent error-correction in performing and providing healthcare. In addition, it is necessary to foresee a correct and professional identification and assessment of the risks that the insurance company assumes by concluding the insurance contract for the professional liability of the physician. In order for the insurer's risk management department to properly assess the risks taken, and to adjust the capital requirements, it is necessary to identify possible errors and damages that may arise in providing the healthcare services. In addition, the physician's unloaded and free reporting of errors will certainly contribute to better risk analysis in this context, which is covered by the professional liability insurance policy in medicine.

\section{References}

Alizadeh, A. H. \& Nomikos, N. K. (2009) Shipping Derivatives and Risk Management (Palgrave Macmillan).

Belanić, L. (1991) Obvezna osiguranja od odgovornosti izvan djelatnosti prometa i prijevoza, Zbornik Pravnog fakulteta Sveučilišta u Rijeci, 30(1), pp. 551-600.

Brandtner, M. \& Kürsten, W. (2014) Solvency II, regulatory capital, and optimale reinsurance: How good are Conditional Value-at-Risk and spectral risk measures?, Insurance: Mathematics and Economics, 59, pp. 156-167, doi: 10.1016/j.insmatheco.2014.09.008.

Bush, J. W., Chen, M. M. \& Bush, A. S. (1975) No-Fault malpractice insurance - Proximate cause and the quality of medical care, Medical jurisprudence, Western Journal of Medicine, 122(3), pp. 262-270.

Čolović, V. \& Petrović, Z. \& Tešić, A. (2015) Osiguranje profesionalne odgovornosti lekara i ostalih zdravstvenih radnika, Vojnosanitetski pregled $=$ Military-medical and pharmaceutical review, 72(1), pp. 82-87, doi: 10.2298/VSP131119021C.

Ćurković, M. (2017) Ugovor o osiguranju - Komentar Zakona o obveznim odnosima (Zagreb: Inženjerski biro). 
Dash Wu, D. \& Olson, D. L. (2015) Enterprise Risk management in Finance (Palgrave Macmillan).

Džidić, M. \& Ćurković, M. (2017) Pravo osiguranja (Mostar: Pravni fakultet Sveučilišta u Mostaru).

Ivanjko, Š. \& Džidić, M. (2017) Zavarovanje odgovornosti kot varstvo pacientov in zdravstvenih delavcev, In: Kraljić, S., Reberšek Gorišek, J. \& Rijavecm V. (eds.) 26. Posvet Medicina, pravo in družba: Varnost pacienta in zdravstvenih delavcev (23. 24. marec 2017, Maribor, Slovenia) (Maribor: Univerzitetna založba Unvierze v Mariboru), pp. 91-103, doi: 10.18690/978-961-286-021-9.

Proso, M. (2007) Osiguranje liječnika od odštetne odgovornosti u hrvatskom i bosanskohercegovačkom pravu, Zbornik radova Aktualnosti građanskog i trgovačkog zakonodavstva i pravne prakse (Mostar: Pravni fakultet Sveučilišta u Mostaru), pp. 689-709.

Proso, M. (2009) Sustavi osiguranja od odštetne odgovornosti u zdravstvenoj djelatnosti, Zbornik radova Pravnog fakulteta u Splitu, 46(2), pp. 359-372.

Radišić, J. (2017) Medicinski standard i odgovornost lekara prema nemačkoj teoriji i sudskoj praksi, Evropska revija za pravo osiguranja, (3), pp. 26-31.

Rakočević, P. (2011) Odgovornost bez krivice medicinskih radnika, Glasnik Advokatske komore Vojvodine, časopis za pravnu teoriju i praksu, 83(71, 1), pp. 19-31.

Serwach, M. (2015) No Fault Insurance System in Polish Law and Other European Legal Systems, Prawo Asekuracyjne, 82(1), pp. 33-45.

Wallis, K. A. (2017) No fault, no difference: no-fault compensation for medical injury and healthcare ethics and practice: debate \& analysis, British journal of General Practice, 67(654), pp. 38-39, doi: 10.3399/bjgp17X688777. 

